\title{
INVENTORY CONTROL OF PRODUCT SUPPLY OF AGRICULTURAL PRODUCT FOR ONLINE SALES (CASE STUDY IN PT INSAN AGRITAMA TEKNOLOGI)
}

\author{
Evi Faridah Rostanti Meliyani, Pandi Pardian. \\ Universitas Padjadjaran. Indonesia. \\ evifaridahrostantimeliyani@gmail.com
}

\begin{abstract}
The industrial revolution 4.0 has encouraged digital technology companies called startup. PT Insan Agritama Teknologi (Inagri) is one of a startup in Bandung City that is engaged in agriculture as a supplier of food ingredients. Inventory of goods in Inagri is currently fulfilled by five partner farmers. At present, Inagri has collaborated with several Horeca (hotel, restaurant, café) and modern retailers to distribute agricultural products. However, for approximately 2.5 years, Inagri has not yet found a standard procedure for inventory control. Sometimes Inagri could not fulfil the demand because there was an out of stock of goods. It is, therefore required to control supplies. The purpose of this study was to identify the process of controlling inventory in Inagri and analysed the classification of inventory in Inagri based on $\mathrm{ABC}$ analysis. This study used the $\mathrm{ABC}$ analysis method. The results showed that the classification of goods inventory in Inagri based on $A B C$ analysis, group A amounted 16 commodities, this amount represented $21 \%$ of total items ( 76 commodities). Group B amounted 17 commodities, or $22 \%$ of total commodity and group C had 43 items or $57 \%$ of total commodities sold by Inagri. $\mathrm{ABC}$ analysis is one of the solutions for making goods stock procurement decisions in the future period.
\end{abstract}

Keywords: Startup, Inventory Control, ABC Analysis

\section{INTRODUCTION}

The industrial revolution 4.0 has encouraged digital technology companies called startup. The startup aims to provide solutions to all problems, such as problems in agriculture, animal husbandry and fisheries.

West Java has a program that supports the startup. Those superior: programs such as the establishment of industrial policy to the different innovations, public service and the region's construction of the industries in the west Java city district, especially small businesses the preparation of digital, economic infrastructure an incubator business and creative/startup Company (uumas Jabar, 2018). 
West Java province known as the main producer of rice, is also a Sentra vegetable in Indonesia. Of the farming, vegetable crops have become part of the local community, especially for farmers the highlands of. In total, the potential broad harvest vegetables in west java became more concentrated among several regions. The concentration of broad share harvest vegetables $>10 \%$ Bandung and Garut is found in the district (Darwis, Muslim, 2013).

Is one of startup Inagri unique in Bandung because they do not forget the original culture as a country Agraria. The idea Inagri 2016, started from the end of this year who solve the problem agricultural supply chain by presenting platform could facilitate direct. Farmers with a This can be cut long supply chain so that the price farmers can be more expensive for farmers; the marketing is very important because agriculture must be in distribution remember characteristic, perishable agricultural products easily foul and voluminous.

To address this, Inagri is agricultural startup that has a purpose of empowering local farmers by providing agricultural market commodities online retail business, hotel, restaurant, and industry food processing. Since released in 2016, Inagri has five partner farmers.

Inagri are considered important to be researched because in the more or less 2.5 years, that were initiated one of them is by alumni of the faculty of agriculture unpaid is in fact already have received many awards for innovation and urban solutions is being offered to the issues food security that market and they answer the needs. One of the successes was Inagri tribute officer of government west java province the year 2018 .

In the business, Inagri is having problems in getting supplies. Supply of inventory management who serves as a one way to do to win the business competition. With supplies that mature, companies can minimize loss due to the shortage of goods, excess goods and the cost of handling the goods and can maximize shareholder profit. In its traditional definition inventory is a current asset, because inventory will usually be converted into cash or other assets in the company's operating cycle (Tuanakotta, 2000).

Supplies have a very important role for the company huge supplier of because in business activities is usually not there are the production process only distribute various a type of product, sell the product in the form of raw or raw materials. The goods sold Inagri quite a lot there are more than 150 commodities.

On the online business, in agriculture, the goods frequent quickly and precisely, so there needs to be effective and efficient control of its business to smooth (Waters, Donald. 2008). In monitoring an inventory of goods in a population that has very much, items needed a grouping of priority goods.

Supplies in Inagri currently met by farmers five partners. However, sometimes Inagri not meet the demand that is out of stocks in Inagri. Inagri always wants to guarantee the availability of it, so when he is running out of employees directly spending goods resulting in the procurement to lack of order was caused by both goods outside schedule supply.

Control supplies on Inagri could not find the raw. Both goods that occur outside schedule supply and the absence of a vehicle inventory causing increased cost store, as the cost of transporting for using private cars and shopping costs prices of other commodities because becoming more expensive if the number of buying a little. To avoid the spending outside schedule supply, then strategy to determine 
supplies to be corrected, thus the costs supplies can be added. Inventory of goods is the main resource in almost all distribution activities in the world, companies can have strong competitiveness when the company can secure its inventory because the availability of goods that are not stable business activities will be hampered by various problems.

In general, inventory consists of various types of goods that are very many in number, where each type of item requires its own analysis to determine the order and point of order. It is realized that not all types of goods in inventory have the same priority level. To find out which types of goods need priority, ABC analysis is used which can classify all types of goods based on their level of importance (Tersine, 1994).

Criteria each class in the classification of $\mathrm{ABC}$ :

1. Class a: supplies having the value of the annual the rupiah which high volume. This class represent around $70 \%$ of the total value of supplies, and the volume is only $20 \%$ of all items. Not be of supply in this class of requiring attention that is high in from the high fees as well as the procurement. The security must the intensively.

2. Class b: supplies with a value of the rupiah annual volume that is intermediate. This group representing approximately $20 \%$ of annual supplies of the total value of, and around $30 \%$ of the number of items. Here takes a stunning piece of control technique moderate.

3. Class c: goods with a value just ask low annual volume, which only represents $10 \%$ of the total value of supplies, but consisting of almost $50 \%$ of the number of items supplies. Here takes a stunning piece of control simple technique, control should only be charged every once in a while.

Based on these, the purpose of this study is to identify the process control supplies in Inagri and analyses classifications supplies in Inagri abc analysis (Assauri, Sofjan, 2004). This method aims to be a solution order to obtain information for a decision making the supply of the next procurement.

\section{METHODOLOGY}

Location and Time of Research: The research was conducted at PT. Insan Agritama Teknologi (Inagri) Jl. Kacapi No. 24 RT 01/ RW 02 Sub-district Lengkong, Bandung City, Jawa Barat. The time of the study was a whole from December 2018 which began with the preparation of research proposals to the writing of research reports.

Research Objects: The object of this research is inventory control of product supply of agricultural products for online sales in Inagri.

Research Instruments: The instruments used in this study are pencils, data collection forms, and Microsoft Excel software.

Design and Technique Research: The research design used in this research is qualitative. Qualitative research is research with strategies that are interactive and 
flexible to understand social phenomena in the research area (Creswell, J.W. 2014). The research technique used in this research is a case study. A case study is process research who studies an event, the process of, and to a group of activity or individual. A case study used to provide a deeply associated with the problem matter to be researched and provide a possible solution to that problem (Stake, R.E. 1995).

Types and Data Sources used

The type of data in this study consisted of:

1. Quantitative Data, data obtained by the company in the form of numbers, there are:

- Amount of Purchase (Kg)

- Total Sales (Kg)

- Selling Price (Rupiah)

- Purchase price (Rupiah)

2. Qualitative Data, data obtained in the form of information both oral and written not numbers about the company, there are:

- The process of inventory control in Inagri

- The process of distributing agricultural products

- Consumers list

- Partner farmers list

Data Sources

Data sources in this study were obtained from:

1. Primary Data: Data obtained by making direct observations (observations) and interviews directly with relevant parties at Inagri

2. Secondary Data : This data is obtained from various sources of books, journals, existing literature, and report on the demand for, the price, the sale for a year in the period January - December 2018.

The method used is ABC analysis : (Herjanto, Eddy. 2007) first step to being done in making abc analysis is classifying the product to determine the priority items that will further analysis, kind of analysis unpaid used is an analysis based on the use of most of the high investment value. The steps or procedures for classifying goods in $\mathrm{ABC}$ usage analysis with calculations through the use of Microsoft Excel applications as follows:

1. Calculate the annual volume of rupiah by multiplying the annual volume at a price per unit.

2. Arrange the order of inventory items based on the annual volume of the rupiah from the largest value to the smallest.

3. Add the annual volume of the rupiah cumulatively

4. Calculate the cumulative percentage value

5. Classify $\mathrm{A}, \mathrm{B}$, and $\mathrm{C}$ respectively by around $70 \%, 20 \%$ and $10 \%$ from above.

6. Describe the $\mathrm{ABC}$ analysis curve (Pareto diagram) to show the level of importance of the item. 


\section{RESULTS AND DISCUSSION General Description of Inagri}

PT. Insan Agritama Teknologi (Inagri) is located in Jl. Kacapi No. 24 RT 01/ RW 02 Sub-district Lengkong, Bandung City, Jawa Barat. PT. Insan Agritama Teknologi (Inagri) is agriculture platform that supplies agri goods and provide purchasing services for Hotel, Restaurant and Catering. Where business can buy raw food materials to supply their business and also plan fresh stock in kitchen. Inagri provides best grade product from vendors and farmer.

\section{Application of the ABC Analysis}

Data used to calculate abc analysis based on the use of archive is based on sales of agricultural commodities are viewed from the customers most frequently order during the year 2018. It noted that during the year 2018 Inagri sell 76 a kind of an item of merchandise derived from agricultural products horticulture. After knowledge, the commodities purchased by consumers that were most often order hence writers analyzing the abc based on discharging for any agriculture commodity. The result from an analysis of the abc there are in table 1 .

Table 1. The Result of ABC Analysis

\begin{tabular}{|l|l|l|l|l|}
\hline Class & Number of Item & \multicolumn{1}{|c|}{$\%$} & $\begin{array}{c}\text { Number of } \\
\text { Use }\end{array}$ & $\%$ \\
\hline A & 16 & 21 & 2581.32 & $75.32 \%$ \\
\hline B & 17 & 22 & 591.48 & $17.26 \%$ \\
\hline C & 43 & 57 & 254.35 & $7.42 \%$ \\
\hline Total & $\mathbf{7 6}$ & $\mathbf{1 0 0}$ & $\mathbf{3 4 2 7 . 1 4}$ & $\mathbf{1 0 0 \%}$ \\
\hline
\end{tabular}

From an analysis of the abc table 1 . It was discovered that class A possesses the 16 , items as commodities this number is 21 per cent of all items many 76 commodities. Meanwhile, the number of the commodities at class a reach 2581.32 $75.32 \mathrm{~kg}$ or as many as percent of the total of all the products sold and the rest $3427.14 \mathrm{~kg}$. Group B has as many as the number of items 17 types of items or 22 amounting to percent of all types of commodities, usage 17.26 reach percent of all percent $591.48 \mathrm{~kg}$ and the rest. Group $\mathrm{C}$ has the number of items 43 some types of items or 57 amounting to percent of all types of commodities and the usage 7,42 only percent of all usage 254.35. And the result can be seen that a group having the least, items but contributed mostly in sales as the c have the items most and contribute the least in selling goods, This is in accordance with a law of the pareto who said Thursday he that only a few goods are a high value and is largely used for many other local artists of little worth .The following a diagram of the results of groupings by of merchandise based on a method of the Australian broadcasting corporation discharging table 1 . 


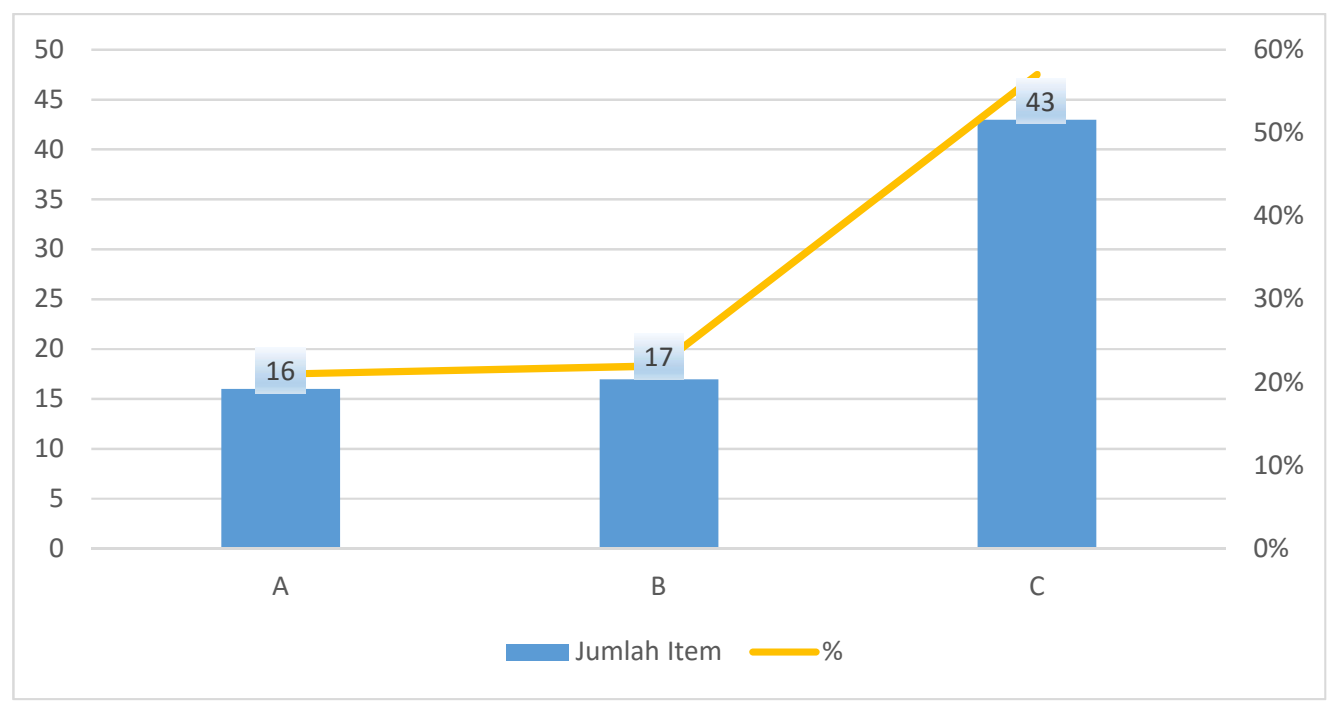

Figure 1. Number of goods item

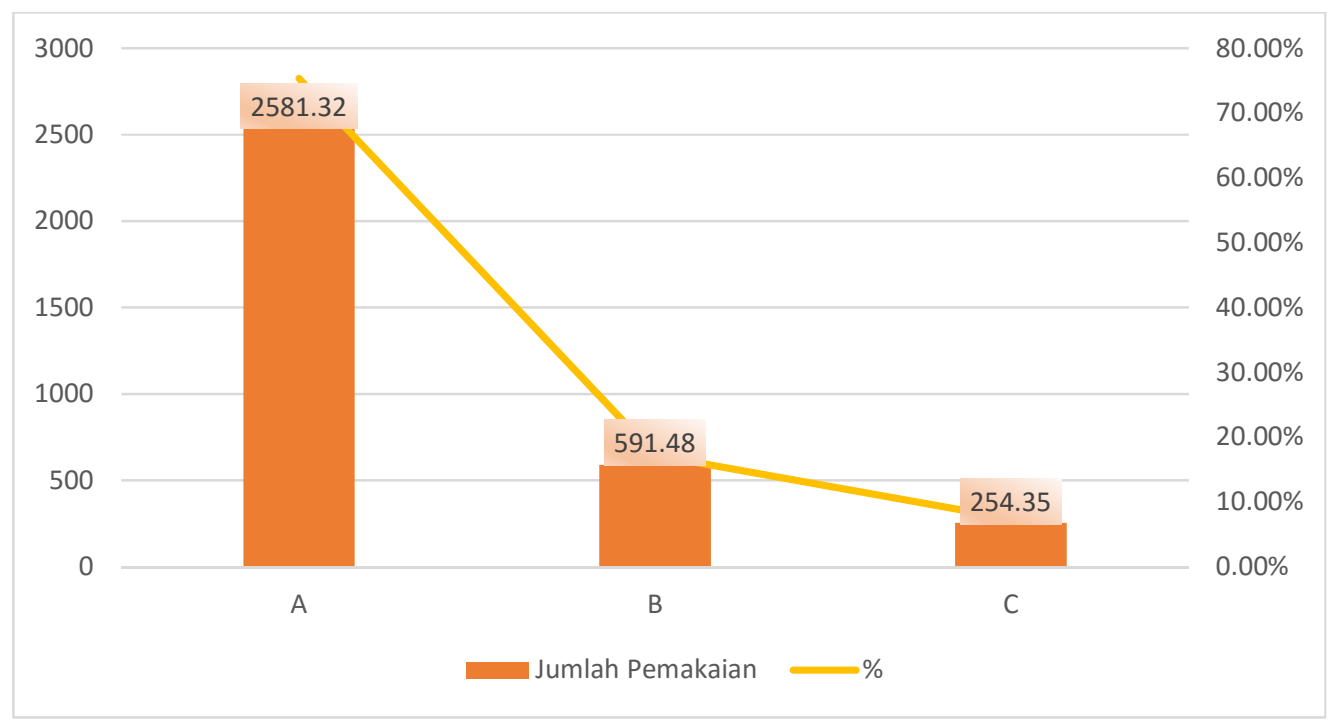

Figure 2. the number of discharging goods

It appears that the percentage discharging goods by kind of stuff inversely, it is a picture of law pareto. Diagram pareto of the results of above is presented in figure 3 


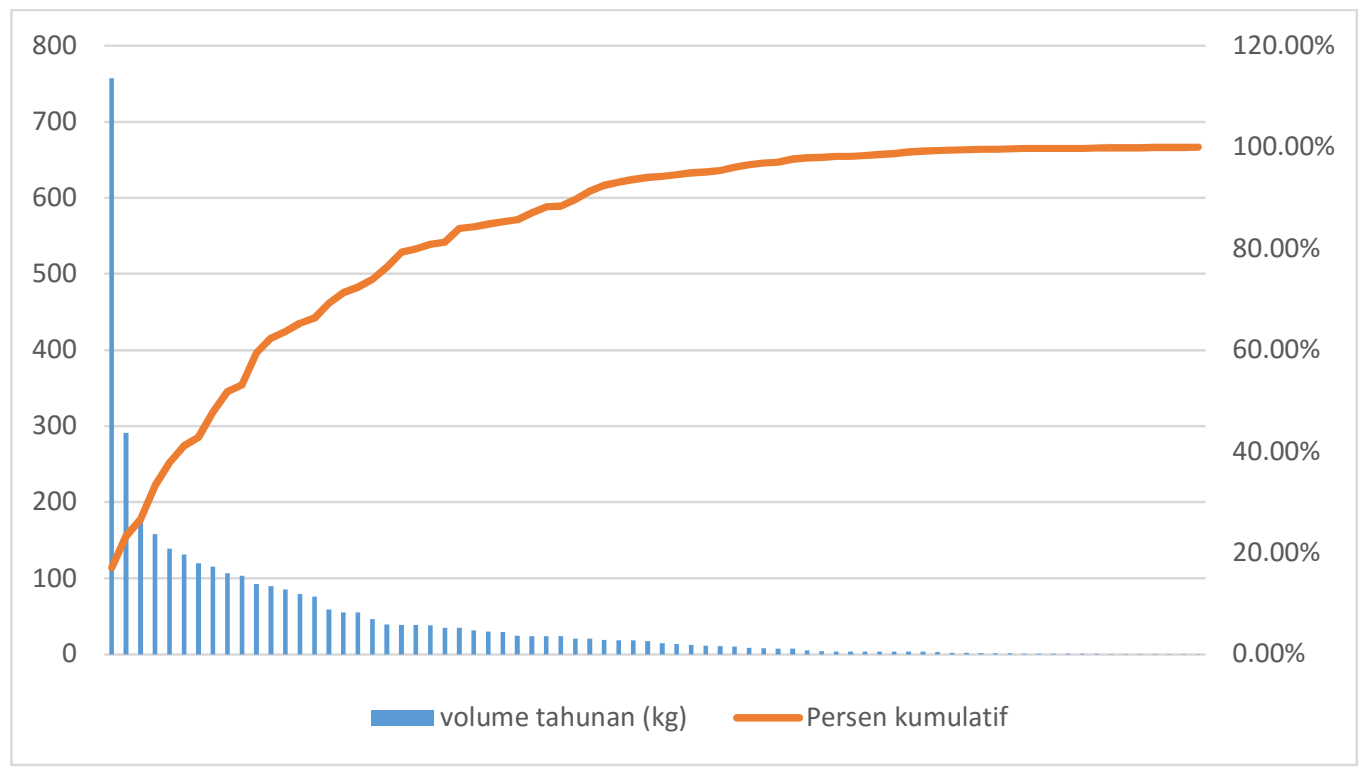

Figure 3. The chart of the calculation on abc discharging Pareto

\section{CONCLUSION}

Based on the results of the inventory control analysis carried out in this study, it can be concluded:

1. The process of controlling goods carried out by Inagri City of Bandung has not been carried out optimally, as evidenced by the absence of systematic planning in inventory control, such as quantity planning, order time, safety inventory, order frequency and also special treatment for high-value-value commodities.

2. The classification of goods inventory in Bandung city Inagri based on ABC analysis is group A totaling 16 commodities, this amount represents $21 \%$ of the total items with 76 commodities. Group B numbered 17 commodities or amounted to $22 \%$ of the total commodity types and group $\mathrm{C}$ had 43 items or $57 \%$ of the total commodities sold by Inagri.

\section{SUGGESTION}

Based on the results of the research described, suggestions that can be recommended are:

1. Ordering goods must always go through the website, by eliminating orders by manual methods so that the purchase planning of goods can be computerized, so that planting planning in the next period can be carried out in accordance with the number of requests so there is no purchase of goods outside the partner farmer supply schedule.

2. Give more treatment to commodities that have high usage quantities such as more frequent checks, more thorough records, more definite planning and 
others. The group of items can be known by doing $\mathrm{ABC}$ analysis, because even though the commodity is small, the amount of usage is the largest.

\section{REFERENCE}

Assauri, Sofjan. 2004 Manajemen Produksi dan Operasi. Jakarta: Prenada Media.

Creswell, J.W. 2014. ResearchDesign: Qualitative, Quantitative, and Mixed Methods Approaches, Edisi 4, London.

Herjanto, Eddy. 2007. Manajemen Operasi. Jakarta: Grasindo.

Humas Jabar. (27 September 2018). Hadapi Revolusi Industri 4.0, Pemprov Jabar Siapkan Program Unggulan. Diakses melalui www.jabarprov.go.id.

Stake, R.E. 1995. The art of case study research. Thousand Oaks, CA : Sage.

Tersine, R.J., 1994. Principles of Inventory and Materials Management, Fourth Edition. New Jersey: Prentice-Hall, Inc. Englewood Cliffs.

Tuanakotta, Theodorus M. S. 2002, Theori Akuntansi. Jakarta : LPFE UI.

Valeriana Darwis, Chairul Muslim. 2013. Keragaan Dan Titik Impas Usaha Tani Aneka Sayuran Pada Lahan Sawah Di Kabupaten Karawang, Jawa Barat. Sepa: Vol. 9 No. 2 Februari 2013: 155 - 162 (2013). ISSN: 1829-9946.

Waters, Donald. 2008. Quantitative Methods for Business. Fourth Edition. England: Pearson Education, Ltd. 